\title{
LITERASI FINANSIAL DAN DIGITAL KELUARGA PEKERJA MIGRAN DITINJAU DARI LATAR BELAKANG PENDIDIKAN
}

\section{FINANCIAL AND DIGITAL LITERACY OF MIGRANT WORKERS' FAMILIES IN TERMS OF EDUCATIONAL BACKGROUND}

\author{
Bayu Adi Laksono, Supriyono, Sri Wahyuni \\ Pendidikan Luar Sekolah, Universitas Negeri Malang \\ Jln. Semarang No. 5 Kota Malang, Jawa Timur \\ E-mail: bayuadi.laksono@yahoo.co.id, supriyono.fip@um.ac.id, \\ sri.wahyuni.fip@um.ac.id
}

Naskah diterima tanggal: 21-04-2019 disetujui tanggal: 17-10-2019

\begin{abstract}
The purpose of this study was to determine the level of financial and digital literacy of migrant workers' families in terms of educational background. This study used a quantitative approach with analysis in the form of analysis of variants and kruskal-wallis. The study was conducted in one village in Lamongan Regency, East Java with a total sample of 95 persons. The results showed that there was no significant difference in the level of financial literacy in terms of the educational background of the families of migrant workers. There is significant differences in the level of digital literacy in terms of the educational background of migrant workers' families. Families of migrant workers who have significant differences in the level of digital literacy are groups of primary school graduates to college graduates and junior secondary school graduates to college graduates. The conclusion of this study is that migrant worker families that tend to have low levels of financial literacy and digital literacy are families of migrant workers with a background in primary school (elementary) and junior secondary school. This is even more convincing that the educational background has an influence on one's ability level. This becomes the identification of migrant worker families with educational background who has priority to get intervention in increasing knowledge and skills in the nonformal education programs that are useful for preparing migrant worker families in the industrial revolution era 4.0.
\end{abstract}

Keywords: digital literacy, financial literacy, family of migrant workers, educational background

\begin{abstract}
Abstrak: Tujuan dari penelitian ini adalah untuk mengetahui tingkat literasi finansial dan digital keluarga pekerja migran ditinjau dari latar belakang pendidikan. Penelitian ini menggunakan pendekatan kuantitatif dengan analysis of varian dan kruskal-wallis. Penelitian dilakukan di salah satu desa di Kabupaten Lamongan, Jawa Timur dengan total sampel sebanyak 95 orang. Hasil penelitian menunjukkan bahwa tidak terdapat perbedaan yang signifikan tingkat literasi finansial yang ditinjau dari latar belakang pendidikan keluarga pekerja migran. Terdapat perbedaan yang signifikan tingkat literasi digital yang ditinjau dari latar belakang pendidikan keluarga pekerja migran. Keluarga pekerja migran yang memiliki perbedaan tingkat literasi digital yang signifikan adalah kelompok lulusan SD dengan lulusan perguruan tinggi serta lulusan SMP dengan lulusan perguruan tinggi. Kesimpulan penelitian ini adalah keluarga pekerja migran yang cenderung memiliki tingkat literasi finansial maupun literasi digital yang rendah adalah keluarga pekerja migran dengan latar belakang lulusan SD dan SMP. Hal tersebut semakin meguatkan bahwa latar belakang pendidikan memberikan pengaruh terhadap tingkat kemampuan seseorang. Identifikasi keluarga pekerja migran dengan latar pendidikan yang memiliki prioritas mendapatkan intervensi peningkatan
\end{abstract}


pengetahuan dan keterampilan berupa program pendidikan nonformal yang berguna untuk mempersiapkan keluarga pekerja migran dalam era revolusi industri 4.0.

Kata Kunci: literasi digital, literasi finansial, keluarga pekerja migran, latar belakang pendidikan

\section{PENDAHULUAN}

Gerakan Literasi Nasional (GLN) mengamanatkan kemampuan literasi yang harus dimiliki masyarakat Indonesia dalam meningkatkan kualitas hidupnya di abad 21 . Kemampuan literasi tersebut di antaranya literasi bahasa (baca tulis), literasi numerasi, literasi sains, literasi digital, literasi finansial, serta literasi budaya dan kewargaan. GLN mengamanatkan tiga lingkungan dalam menjalankan gerakan tersebut, yakni gerakan literasi keluarga, gerakan literasi sekolah, dan gerakan literasi masyarakat.

Peran dan fungsi peningkatan literasi masyarakat, bukan hanya tanggung jawab pendidikan formal, melainkan juga bagian tanggung jawab dari pendidikan nonformal dan informal. Pendidikan nonformal dan informal bahkan memiliki peran yang strategis. Hal ini karena kalangan pelajar lebih banyak menghabiskan waktu di luar jam sekolah begitu pula dengan masyarakat umum (bukan usia sekolah) yang tentunya lebih banyak beraktivitas dalam ranah keluarga dan masyarakat. Kemampuan literasi tersebut juga harus dikombinasikan dengan kompetensi berfikir kritis, kreativitas, komunikasi, dan kolaborasi. Selain GLN, Otoritas Jasa Keuangan (OJK) juga fokus pada kajian literasi, yakni literasi finansial.

Literasi keuangan atau finansial merupakan pengetahuan, keterampilan, dan keyakinan yang memengaruhi sikap dan perilaku untuk meningkatkan kualitas pengambilan keputusan dan pengelolaan keuangan dalam rangka mencapai kesejahteraan (Otoritas Jasa Keuangan, 2017). OJK menyatakan bahwa misi penting dari program literasi keuangan atau finansial adalah untuk melakukan edukasi di bidang keuangan kepada masyarakat.
Masyarakat diharapkan dapat mengelola keuangan secara cerdas, bisa mengatasi rendahnya pengetahuan tentang industri keuangan, dan masyarakat tidak mudah tertipu pada produk-produk investasi yang menawarkan keuntungan tinggi dalam jangka pendek tanpa mempertimbangkan risikonya. Literasi finansial merupakan hal yang sangat vital dalam proses menuju kesuksesan pengelolaan keuangan.

Literasi finansial dimaknai sebagai kemampuan seseorang untuk mengelola informasi yang sesuai dengan tujuan dalam pengambilan keputusan dengan mempertimbangkan dampak finansial yang ditimbulkannya (Mason \& Wilson, 2000). Definisi tersebut dilengkapi dengan kajian yang menyatakan bahwa literasi keuangan atau finansial merupakan kemampuan untuk mencermati, menganalisis, mengatur, dan mengomunikasikan kondisi keuangan. Hal tersebut untuk mencapai kesejahteraan, termasuk di dalamnya kemampuan untuk melihat pilihan produk keuangan, memahami isu-isu keuangan, merencanakan masa depan, dan kemampuan memahami keputusan keuangan yang dilakukan sehari-hari (Huston, 2010).

Berdasarkan beberapa kajian tersebut di atas dapat ditarik kesimpulan, bahwa literasi finansial merupakan kemampuan seseorang dalam mengelola keuangan secara teknis dan kemampuan memprediksi serta mempertimbangkan risiko-risiko yang diambil dalam kegiatan keuangan. Sejalan dengan kesimpulan tersebut, literasi finansial didefinisikan juga sebagai kemampuan dan keterampilan seseorang dalam pengambilan keputusan pengelolaan keuangan, yang terbagi dalam beberapa indikator yakni kemampuan penganggaran, pemahaman konsep tabungan, 
pertimbangan risiko pinjaman, dan investasi (Remund, 2010).

Selain literasi finansial salah satu objek yang dikaji yakni mengenai literasi digital. Literasi digital dimaknai sebuah kemampuan untuk memahami dan menggunakan informasi dari berbagai sumber digital (Gilster, 1997). Kompetensi inti dari literasi digital dapat dikategorikan menjadi empat, yakni pencarian di internet, pandu arah hypertext, evaluasi konten informasi, dan penyusunan pengetahuan. Kategori dan pemaknaan tersebut cenderung lebih fokus pada kemampuan kognitif seseorang dalam menyikapi informasi pada dunia digital, bukan hanya keterampilan dalam menggunakan perangkat digital. Pendapat lain menyatakan bahwa literasi digital merupakan pengetahuan, keterampilan, dan penguasaan baik sumber informasi maupun perangkat digital (Eisenberg, 2010). Setiap orang yang mampu memanfaatkan perangkat digital yang terbaru dicitrakan sebagai penggenggam masa depan.

Berdasarkan beberapa kajian tersebut dapat disimpulkan bahwa literasi digital merupakan kemampuan dan keterampilan dalam mengatur sebuah informasi dalam dunia digital yang didukung oleh keterampilan dalam pengoperasian perangkat digital yang ada. Terdapat tujuh indikator untuk mengukur kemampuan dan keterampilan literasi digital seseorang (Beetham, McGill, \& Littlejohn, 2009). Indikator tersebut adalah literasi informasi, kegiatan digital akademik, kemampuan belajar, literasi TIK, manajemen privasi, komunikasi dan kolaborasi, serta literasi media.

Literasi finansial maupun digital merupakan dua hal yang patut menjadi fokus pada keluarga pekerja migran. Pengetahuan dan keterampilan dalam mengambil keputusan keuangan mutlak diperlukan keluarga pekerja migran karena manajemen keuangan hasil dari bekerja di luar negeri tentu pada akhirnya akan dikelola oleh keluarga pekerja migran di Indonesia. Akan menjadi hal yang sangat riskan jika keluarga pekerja migran tidak mamahami dalam mengambil keputusan keuangan. Kemampuan seseorang dalam menata keuangan yang baik akan menunjukkan perilaku keuangan yang sehat dan terhindar dari masalah keuangan (Chinen \& Endo, 2012). Sejalan dengan kemampuan dalam mengambil keputusan keuangan, kemampuan memanfaatkan dunia digital juga menjadi hal yang mutlak dikuasai oleh keluarga pekerja migran. Keterbatasan jarak dan waktu akan sangat terbantu apabila keluarga pekerja migran mampu memanfaatkan dunia digital, terutama dalam berkomunikasi.

Latar belakang pendidikan seseorang menentukan kecerdasan dalam pengambilan keputusan dan pengelolaan ekonomi (Sitorus, 2017). Selain itu latar belakang pendidikan seseorang juga berpengaruh terhadap kemampuan literasi informasi termasuk di dalamnya pengelolaan sumber informasi elektronik (Samosir, 2014). Hasil penelitian ini berguna untuk mengukur keadaan dan tingkat literasi finansial dan digital keluarga pekerja migran.

Berdasarkan kajian tersebut keluarga pekerja migran mampu memahami keadaan, terutama kekurangannya dalam penguasaan literasi finansial dan digital, sehingga memungkinkan para keluarga pekerja migran untuk terus meningkatkan kemampuan diri dengan belajar. Sejalan dengan fakta dan tindak lanjut yang dihasilkan dari penelitian ini, keluarga pekerja migran dapat mempersiapkan diri pada revolusi industri 4.0 dengan memiliki penguasaan literasi finansial dan digital yang memadai. Revolusi industri 4.0 menghadapkan manusia pada keadaan yang berhubungan dengan dunia digital.

\section{METODE}

Penelitian ini dilaksanakan di Payaman, Solokuro, Kabupaten Lamongan pada bulan Januari hingga Maret 2019. Desa Payaman merupakan salah satu desa yang memiliki jumlah pekerja migran 
yang tinggi, sehingga dijuluki dengan nama "Desa TKI". Penelitian ini menggunakan pendekatan kuantitatif dan menggunakan analisis of varian dan kruskal-wallis dalam proses analisis datanya. Cluster random sampling digunakan dalam menentukan responden yang memberikan setiap anggota populasi memiliki potensi terpilih yang sama besar berdasarkan wilayah (cluster). Angket diberikan kepada anggota keluarga pekerja migran yang memiliki otoritas dan pengaruh dalam manajemen keluarga. Jumlah besaran sampel penelitian menggunakan Nomogram Harry King (King, 1978) dengan menggunakan derajat kesalahan sebesar $9 \%$ (berarti derajat kepercayaan 91\%).

Tabel 1 Jumlah Pekerja Migran dan Sampel Penelitian

\begin{tabular}{lccc}
\hline \multicolumn{1}{c}{ Dusun } & Pekerja & $\%$ & Sampel \\
\hline Sawo & 413 & $25 \%$ & 23 \\
Ringin & 276 & $17 \%$ & 16 \\
Asem & 345 & $21 \%$ & 20 \\
Gayam & 343 & $21 \%$ & 19 \\
Sejajar & 14 & $1 \%$ & 1 \\
Bango & 69 & $4 \%$ & 4 \\
Palirangan & 207 & $12 \%$ & 12 \\
& 1667 & $100 \%$ & 95 \\
\hline
\end{tabular}

Sampel dalam penelitian ini sebanyak 95 orang, representasi dari masyarakat pekerja migran yang berada di Desa Payaman, Solokuro, Kabupaten Lamongan (Tabel 1). Penelitian menggunakan angket berskala likert serta menggunakan Analisis of Varian dan KruskalWallis dalam analisis datanya.

\section{HASIL DAN PEMBAHASAN}

\section{Hasil}

Pada bagian ini dipaparkan mengenai keadaan nyata hasil kajian dari penelitian mengenai tingkat masing-masing variabel yang ada. Pembagian tingkatan tersebut berdasarkan jumlah hasil perhitungan dari instrumen yang telah diisi oleh responden kemudian dianalisis menggunakan Microsoft Excel 2007. Kategori tingkat literasi dibedakan menjadi tiga (Chen \& Volpe, 1998) yakni: kategori literasi rendah dengan indikasi $<60 \%$ total skor, kategori literasi sedang dengan indikasi $60 \%-79 \%$ total skor, kategori literasi tinggi dengan indikasi $>79 \%$ total skor.

Berdasarkan instrumen yang telah disusun, variabel literasi finansial memiliki total 10 pernyataan. Dengan demikian, skor minimal yang dapat diperoleh adalah 10 dan skor maksimal yang mampu diperoleh adalah 40 yang kemudian disesuaikan dengan kriteria persentase di atas. Sejalan dengan variabel literasi finansial, variabel literasi digital memiliki total 18 pernyataan, sehingga skor minimal yang dapat diperoleh adalah 18 sedangkan skor maksimal yang diperoleh adalah sebanyak 72 yang kemudian disesuaikan dengan kategori tingkat literasi di atas. Tabel 2 adalah kriteria pembagian tingkatan masing-masing variabel.

Tabel 2 Kriteria Tingkatan Variabel Literasi Finansial dan Digital

\begin{tabular}{llll}
\hline \multirow{2}{*}{ Tingkat } & \multirow{2}{*}{ Kriteria } & \multicolumn{2}{c}{ Rentang } \\
\cline { 3 - 4 } & & Finansial & Digital \\
\hline Tinggi & $>79 \%$ & $33-40$ & $58-72$ \\
Sedang & $60 \%-79 \%$ & $24-32$ & $43-57$ \\
Rendah & $<60 \%$ & $10-23$ & $18-42$ \\
\hline
\end{tabular}

\section{Tingkat Literasi Finansial Keluarga Pekerja Migran}

Tingkat literasi finansial keluarga pekerja migran di Desa Payaman Kecamatan Solokuro Kabupaten Lamongan mengacu pada kriteria yang telah ada. Berdasarkan hasil penelitian didapatkan gambaran mengenai tingkat literasi finansial $4 \%$ masuk pada kategori rendah, $78 \%$ termasuk dalam kategori literasi finansial sedang dan lainnya masuk dalam kategori literasi yang tinggi sebesar 18\% (Gambar 1).

Hasil tingkat literasi finansial keluarga pekerja migran dipertajam dengan analisis 


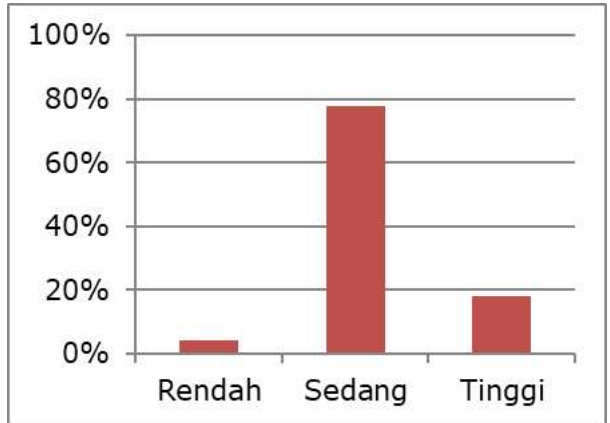

Gambar 1 Tingkat Literasi Finansial

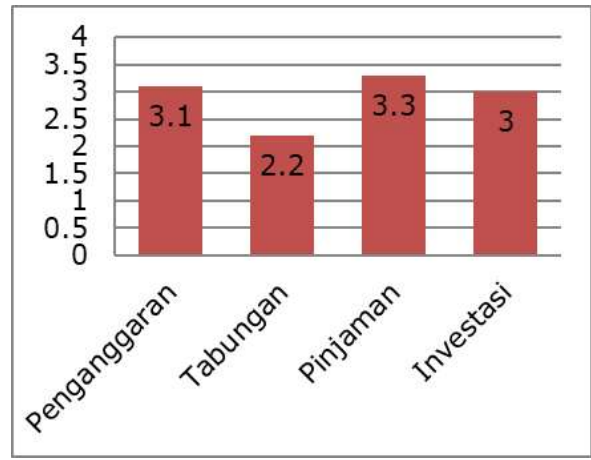

Gambar 2 Indikator Tingkat Literasi Finansial

deskriptif indikator yang ada pada literasi finansial. Hasil secara deskriptif masing-masing indikator pada literasi finansial menunjukkan bahwa indikator tabungan merupakan indikator dengan nilai paling sedikit di antara indikator lain (Gambar 2).

\section{Tingkat Literasi Digital Keluarga Pekerja Migran}

Tingkat literasi digital keluarga pekerja migran di Desa Payaman Kecamatan Solokuro Kabupaten Lamongan berdasarkan kriteria yang telah disusun. Berdasarkan hasil kajian didapatkan gambaran mengenai tingkat literasi digital keluarga pekerja migran yaitu $11,6 \%$ yang masuk dalam kategori tingkat rendah. Kemudian $74,7 \%$ termasuk literasi sedang dan sisanya sebanyak 13,7\% masuk dalam kategori literasi tingkat tinggi (Gambar 3).

Hasil analisis deskiptif menunjukkan bahwa tingkat literasi digital masuk pada kategori sedang. Hasil dari tingkat literasi digital diperkuat dengan analisis deskriptif masing-masing indikator. Hasil analisis masing-masing indikator

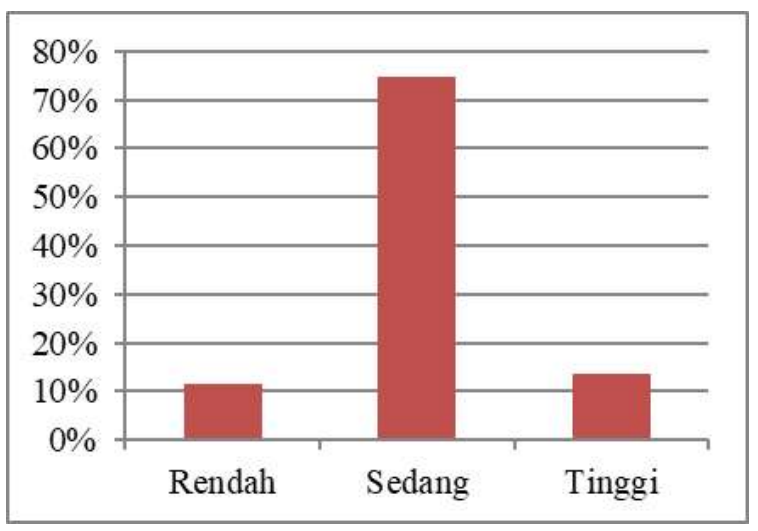

Gambar 3 Tingkat Literasi Digital

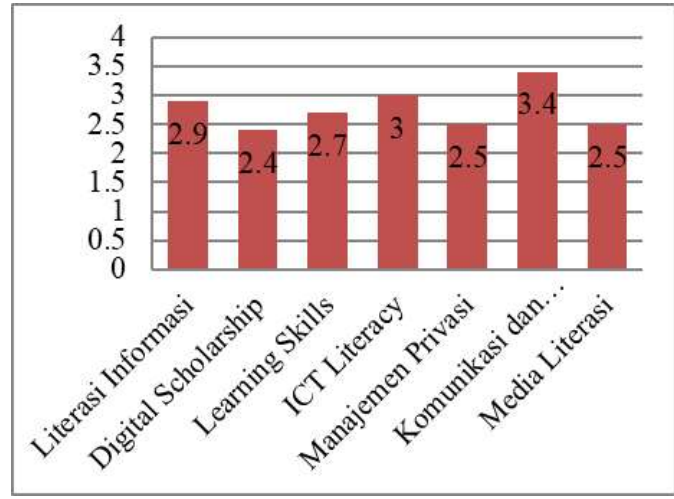

Gambar 4 Indikator Tingkat Literasi Digital

literasi digital menunjukkan bahwa indikator Digital Scholarship merupakan indikator dengan nilai rata-rata yang paling rendah (Gambar 4).

\section{Analisis Varian}

Dalam bagian ini dipaparkan kajian mengenai tingkat literasi finansial dan digital keluarga pekerja migran ditinjau dari latar belakang pendidikan. Pada bagian analisis varian digunakan Analysis of Varian (One Way Anova) jika asumsi normalitas dan homogenitas terpenuhi dan menggunakan analisis Kruskal-Wallis sebagai alternatif jika asumsi normalitas dan homogenitas tidak terpenuhi. Pada masingmasing uji statistik terdapat kriteria dalam interpretasinya (Tabel 3).

\section{Tingkat Literasi Finansial ditinjau dari Latar Belakang Pendidikan}

Sebelum analisis data, terlebih dahulu uji normalitas dan uji homogenitas. Dalam uji 
Tabel 3 Kriteria Masing-Masing Uji Statistik

\begin{tabular}{lll}
\hline \multicolumn{1}{c}{ Jenis Uji } & \multicolumn{1}{c}{ Kriteria } & \multicolumn{1}{c}{ Interpretasi } \\
\hline Uji Normalitas & Nilai Sig. $>0,05$ & Data Normal \\
Uji Homogenitas & Nilai Sig. $>0,05$ & Data Homogen \\
Uji One Way Anova & Nilai Sig. > 0,05 & Tidak Terdapat Perbedaan \\
Uji Kruskal Wallis & Nilai Asymp. Sig. >0,05 & Tidak Terdapat Perbedaan \\
Post Hoc & Nilai Sig. >0,05 & Tidak Memiliki Rata-Rata Perbedaan \\
\hline
\end{tabular}

Sumber: Iskandar (2008)

normalitas digunakan metode KolmogorovSmirnov dan atau Shapiro-Wilk (Tabel 4).

Tabel 4 Uji Normalitas Data Pendidikan Dengan Literasi Finansial

\begin{tabular}{lcccc}
\hline \multirow{2}{*}{ Pendidikan } & \multicolumn{2}{c}{ Kolmogorov- } & & \\
& \multicolumn{2}{c}{ Smirnov } & \multicolumn{2}{c}{ Shapiro-Wilk } \\
\cline { 2 - 5 } & $\mathrm{df}$ & Sig. & Df & Sig. \\
\hline Lulus SD & 6 &, 200 & 6 &, 291 \\
Lulus SMP & 17 &, 200 & 17 &, 821 \\
Lulus SMA & 60 &, 200 & 60 &, 470 \\
Lulus PT & 12 &, 091 & 12 &, 156 \\
\hline
\end{tabular}

Hasil uji normalitas menggunakan Kolmogorov-Smirnov maupun Shapiro-Wilk menunjukkan nilai signifikansi (sig.)>0,05 sehingga data dinyatakan normal. Setelah uji normalitas data adalah uji homogenitas agar syarat analisis of varian dapat terpenuhi (Tabel 5).

Tabel 5 Uji Homogenitas Data Pendidikan Dengan Literasi Finansial

\begin{tabular}{cccc}
\hline $\begin{array}{c}\text { Levene } \\
\text { Statistic }\end{array}$ & df1 & df2 & Sig. \\
\hline 1,829 & 3 & 91 &, 147 \\
\hline
\end{tabular}

Berdasarkan hasil analisis SPSS uji homogenitas diperoleh nilai signifikansi (Sig.) sebesar 0,147, karena nilai signifikansi 0,147>0,05 maka dapat disimpulkan bahwa varian latar belakang pendidikan keluarga pekerja migran yang dibandingkan tersebut adalah sama atau homogen, sehingga asumsi homogenitas dalam uji one way anova terpenuhi.
Setelah uji normalitas dan uji homogenitas terpenuhi, sebelum melanjutkan pada analisis of varian, dikaji nilai rata-rata dari masingmasing kelompok lulusan (Gambar 5).

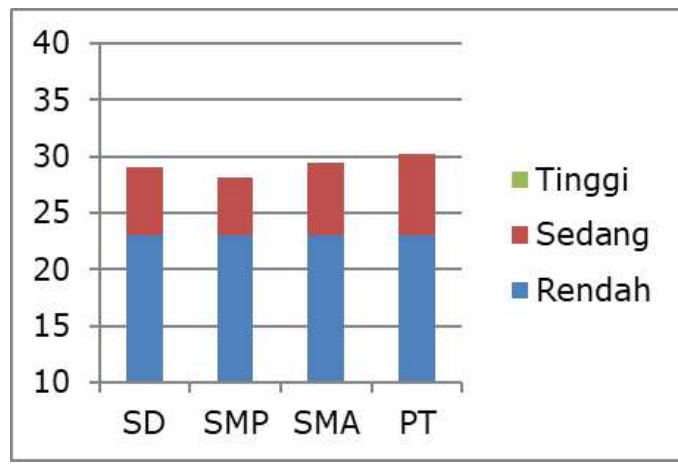

Gambar 5 Rata-rata Tingkat Literasi Finansial Berdasar Pendidikan

Rata-rata tingkat literasi finansial berdasarkan latar belakang pendidikan yakni keluarga pekerja migran kelompok lulusan SD/ sederajat sebesar 29,00. Rata-rata tingkat literasi finansial keluarga pekerja migran kelompok lulusan SMP/sederajat sebesar 28,12. Rata-rata tingkat literasi finansial keluarga pekerja migran kelompok lulusan SMA/sederajat sebesar 29,45. Rata-rata tingkat literasi finansial keluarga pekerja migran kelompok lulusan PT sebesar 30,25.

Setelah uji normalitas dan homogenitas terpenuhi, tahap selanjutnya yakni uji beda menggunakan Analysis of Varian (One Way Anova). Untuk menguji keempat kelompok dari latar belakang pendidikan yang berbeda mempunyai rata-rata yang sama atau berbeda. Jika nilai signifikansi (Sig.) >0,05 maka rata-rata sama, jika <0,05 maka rata-rata berbeda. 
Tabel 6 Uji Anova Literasi Finansial Berdasar Pendidikan

\begin{tabular}{lccc}
\hline & df & F & Sig. \\
\hline Between Groups & 3 & 1,039 &, 379 \\
Within Groups & 91 & & \\
Total & 94 & & \\
\hline
\end{tabular}

Berdasarkan hasil analisis melalui uji anova diketahui nilai signifikansi (Sig.) sebesar 0,379>0,05 sehingga dapat disimpulkan bahwa tidak terdapat perbedaan yang signifikan tingkat literasi finansial yang ditinjau dari latar belakang pendidikan keluarga pekerja migran.

\section{Tingkat Literasi Digital ditinjau dari Latar Belakang Pendidikan}

Sebelum melakukan analisis data, terlebih dahulu pada uji normalitas dan uji homogenitas. Dalam uji normalitas digunakan metode KolmogorovSmirnov dan atau Shapiro-Wilk.

Tabel 7 Uji Normalitas Literasi Digital Berdasar Latar Belakang Pendidikan

\begin{tabular}{lcccc}
\hline \multirow{2}{*}{ Pendidikan } & \multicolumn{2}{c}{ Kolmogorov- } & \multicolumn{2}{c}{ Shapiro-Wilk } \\
\cline { 2 - 5 } & $\mathrm{df}$ & Sig. & $\mathrm{df}$ & Sig. \\
\hline Lulus SD & 6 &, 062 & 6 &, 093 \\
Lulus SMP & 17 &, $200^{*}$ & 17 &, 591 \\
Lulus SMA & 60 &, $200^{*}$ & 60 &, 080 \\
Lulus PT & 12 &, $200^{*}$ & 12 &, 131 \\
\hline
\end{tabular}

Hasil uji normalitas menggunakan Kolmogorov-Smirnov maupun Shapiro-Wilk menunjukkan nilai signifikansi (sig.) >0,05 sehingga data dinyatakan normal. Kemudian dilanjutkan dengan uji homogenitas.

Tabel 8 Uji Homogenitas Literasi Digital Berdasarkan Latar Belakang Pendidikan

\begin{tabular}{cccc}
\hline Levene Statistic & $\mathrm{df1}$ & $\mathrm{df2}$ & Sig. \\
\hline 1,307 & 3 & 91 &, 277 \\
\hline
\end{tabular}

Berdasarkan hasil analisis SPSS uji homogenitas diperoleh nilai signifikansi (Sig) sebesar 0,277, karena nilai signifikansi 0,277>0,05 maka dapat disimpulkan bahwa varian latar belakang pendidikan keluarga pekerja migran yang dibandingkan tersebut adalah sama atau homogen, sehingga asumsi homogenitas dalam uji One Way Anova terpenuhi.

Selain uji normalitas dan uji homogenitas, juga diberikan data deskripsi mengenai ratarata tingkat literasi digital yang dikaji berdasarkan latar belakang pendidikan keluarga pekerja migran (Gambar 6).

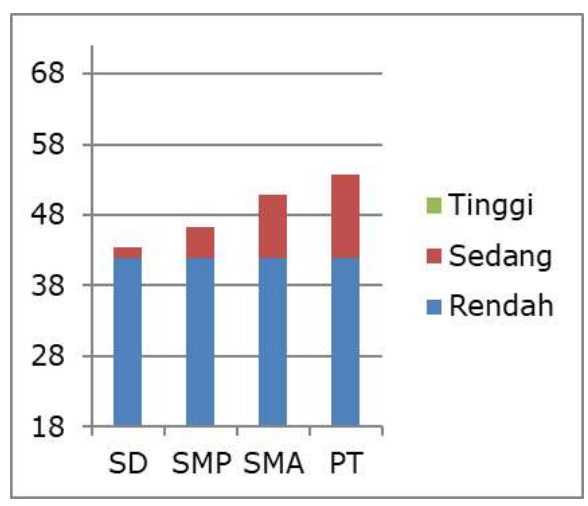

Gambar 6 Rata-rata Literasi Digital Berdasarkan Latar Belakang Pendidikan

Rata-rata tingkat literasi digital berdasarkan latar belakang pendidikan yakni keluarga pekerja migran kelompok lulusan SD/sederajat sebesar 43,5. Rata-rata tingkat literasi digital keluarga pekerja migran kelompok lulusan SMP/Sederajat sebesar 46,3. Rata-rata tingkat literasi digital keluarga pekerja migran kelompok lulusan SMA/ Sederajat sebesar 50,8. Rata-rata tingkat literasi digital keluarga pekerja migran kelompok lulusan PT sebesar 53,8.

Langkah selanjutnya yakni uji Anova, untuk melihat apakah ada perbedaan yang signifikan tingkat literasi digital ditinjau dari latar belakang pendidikan keluarga pekerja migran.

Tabel 9 Uji Anova Literasi Digital Berdasar Latar Belakang Pendidikan

\begin{tabular}{lllll}
\hline & \multicolumn{3}{c}{ Mean } & \\
& $d f$ & Square & $F$ & Sig. \\
\hline Between Groups & 3 & 235,464 & 4,905 &, 003 \\
Within Groups & 91 & 48,004 & & \\
Total & 94 & & & \\
\hline
\end{tabular}


Berdasarkan hasil analisis melalui uji anova diketahui nilai signifikansi (Sig.) sebesar $0,003<0,05$ sehingga dapat disimpulkan bahwa terdapat perbedaan yang signifikan tingkat literasi digital yang ditinjau dari latar belakang pendidikan keluarga pekerja migran. Karena terdapat perbedaan, analisis dilanjutkan pada tahap Post Hoc untuk mengetahui kelompok mana saja yang memiliki perbedaan.

Tabel 10 Analisis Perbandingan Kelompok Pendidikan

\begin{tabular}{lll}
\hline (I) Pendidikan & (J) Pendidikan & Sig. \\
\hline \multirow{4}{*}{ Lulus SD } & Lulus SMP &, 831 \\
& Lulus SMA &, 070 \\
& Lulus PT &, 019 \\
Lulus SMP & Lulus SD &, 831 \\
& Lulus SMA &, 086 \\
& Lulus PT &, 025 \\
Lulus SMA & Lulus SD &, 070 \\
& Lulus SMP &, 086 \\
& Lulus PT &, 527 \\
Lulus PT & Lulus SD &, 019 \\
& Lulus SMP &, 025 \\
& Lulus SMA &, 527 \\
\hline
\end{tabular}

Pengujian Post Hoc menggunakan Tukey HSD berdasarkan hasil SPSS menyatakan bahwa nilai signifikansi (Sig.) $<0,05$ terdapat pada kelompok lulusan SD/sederajat dengan lulusan Perguruan Tinggi (PT), serta lulusan SMP/ Sederajat dengan lulusan Perguruan Tinggi (PT). Hal ini dapat disimpulkan bahwa kelompok Iulusan SD/sederajat dan lulusan Perguruan Tinggi (PT) serta lulusan SMP/sederajat dengan lulusan Perguruan Tinggi (PT) memiliki rata-rata perbedaan tingkat literasi digital yang signifikan.

Tabel 11 Analisis Lanjutan Perbandingan Kelompok Pendidikan

\begin{tabular}{lcccc}
\hline & \multicolumn{4}{c}{ Subset for alpha $=0.05$} \\
\cline { 3 - 5 } Pendidikan & $\mathrm{N}$ & 1 & 2 & 3 \\
\hline Lulus SD & 6 & 43,500 & & \\
Lulus SMP & 17 & 46,294 & 46,294 & \\
Lulus SMA & 60 & & 50,850 & 50,850 \\
Lulus PT & 12 & & & 53,833 \\
Sig. & &, 750 &, 367 &, 710 \\
\hline
\end{tabular}

Untuk melihat kesamaan rata-rata, digunakan hasil analisis Tukey HSD berdasarkan interpretasi pada Tabel 10 menyatakan bahwa tingkat literasi digital kelompok lulusan SD dan SMP tidak memiliki perbedaan yag signifikan. Tingkat literasi digital kelompok lulusan SMP dan SMA tidak memiliki perbedaan yang signifikan. Tingkat literasi digital kelompok lulusan SMA dan PT tidak memiliki perbedaan yang signifikan.

\section{Pembahasan}

Mayoritas keluarga pekerja migran memiliki tingkat literasi finansial yang sedang. Pemahaman dan keputusan keuangan yang dilakukan keluarga pekerja migran tercermin dalam latar belakang penelitian yang lebih dari separuh total remitansi digunakan untuk kegiatan yang sifatnya konsumtif dan sisanya digunakan untuk kegiatan produktif seperti investasi dan menabung. Hal tersebut mengindikasikan bahwa keluarga pekerja migran belum terlalu memahami isu-isu keuangan termasuk keputusan pengelolaan keuangan.

Hasil analisis pada indikator literasi finansial menunjukkan bahwa pengetahuan dan keterampilan menabung keluarga pekerja migran masih tertinggal daripada indikator lainnya pada literasi finansial. Penelitian terdahulu menyatakan bahwa latar belakang pendidikan memberikan pengaruh terhadap keputusan ekonomi sehingga keluarga pekerja migran dalam meningkatkan literasi finansialnya adalah melalui pendidikan.

Keterampilan dan pengetahuan keluarga pekerja migran mengenai pengelolaan keuangan lebih khusus bidang tabungan hanya dapat ditingkatkan melalui kegiatan belajar pada jalur pendidikan nonformal, karena keterbatasan pendidikan formal menampung kebutuhan belajar keluarga pekerja migran. Kebutuhan pendidikan keluarga pekerja migran dapat dipenuhi melalui jalur pendidikan nonformal seperti program pelatihan. Kelebihan pendidikan nonformal dari pendidikan jalur lainnya adalah integrasi dan 
kesesuaian materi belajar dengan kebutuhan belajar (Ansori \& Samsudin, 2013).

Pelaksanaan pembelajaran pada pendidikan nonformal tidak terikat pada batas administratif seperti usia, waktu, dan tempat. Alasan itulah yang mendasari keluarga pekerja migran dapat meningkatkan kapasitas akademik maupun keterampilannya meskipun tidak lagi berada pada usia sekolah. Sejalan dengan hal tersebut, pada era revolusi industri 4.0 ini memberikan kemudahan yang luar biasa dalam mengakses program pendidikan melalui gawai dan jaringan internet. Keluarga pekerja migran tidak perlu mengkhawatirkan mengenai program dan penyelenggaraan waktunya. Hal ini karena beragamnya pilihan jenis pelatihan termasuk dalam pengembangan keterampilan bidang finansial.

Tingkat literasi digital keluarga pekerja migran mayoritas masuk dalam ketegori sedang. Berbeda dengan tingkat literasi finansial yang tingkatan kategorinya sangat rendah dalam literasi digital tingkat kategori rendah hampir seimbang dengan kategori tinggi yang hanya terpaut $2 \%$. Hal ini sejalan dengan sebuah kajian yang menyatakan bahwa masyarakat desa belum dapat memaksimalkan peran teknologi informasi yang ditandai dengan kadar tingkat literasi yang rendah cenderung sedang (Alas, 2018). Tingkat literasi digital keluarga pekerja migran berada pada tingkat sedang, yang ratarata usia usianya berada pada usia 35,3 tahun

Dalam kajian penelitian ini literasi digital diukur indikatornya. Hasilnya menunjukkan bahwa dari tujuh indikator, literasi perangkat digital (ICT) serta komunikasi dan kolaborasi merupakan indikator yang paling tinggi nilainya. Hasil kajian tersebut semakin menguatkan dugaan bahwa keluarga pekerja migran masih memanfaatkan dunia digital dengan sangat sederhana.

Indikator pada literasi digital seperti pemanfaatan dunia digital sebagai peningkatan keterampilan belajar (learning skills) serta kegiatan peningkatan kualitas akademik (digital scholarship) masih pada tataran rendah. Kesenjangan pemanfaatan dunia digital pada keluarga pekerja migran dapat diperkecil dengan mengkondisikan keluarga pekerja migran dalam program pemberdayaan berupa pelatihan pemanfatan dunia digital dalam meningkatkan ekonomi keluarga.

Sistem pendidikan nasional mengamanatkan tiga jalur pendidikan yakni formal, nonformal, dan informal. Ketiga jalur tersebut dapat saling melengkapi dan memperkaya. Dalam rangka peningkatan literasi khususnya literasi digital masyarakat perlu didorong pada penguasaan perangkat digital.

Era revolusi industri 4.0 membuat masyarakat berpindah dari teknologi manual menuju teknologi digital. Masyarakat yang tidak menguasai teknologi akan tertinggal informasi mengenai sekitarnya. Era revolusi industri 4.0 menye-babkan konsekuensi yakni menyiapkan sumber daya yang memiliki nilai kemanusiaan serta sumber daya yang sesuai dengan kebutuhan industri (Prasetyo \& Trisyanti, 2018). Keluarga pekerja migran yang memerlukan komunikasi dengan anggota keluarga di luar negeri, diharapkan dapat menguasai perangkat digital agar meminimalisir biaya komunikasi serta menjaga hubungan agar tetap intens. Kemampuan literasi digital yang dimiliki seseorang memiliki dampak positif terhadap pengetahuan, pemahaman dan keterampilan dalam memahami sumber informasi (Silvana \& Darmawan, 2018). Hal tersebut semakin menguatkan bahwa dalam era revolusi industri 4.0, masyarakat harus semakin terbuka terhadap perubahan yang ada.

\section{Literasi Finansial Ditinjau Dari Latar Belakang Pendidikan Keluarga Pekerja Migran}

Berdasarkan hasil temuan dalam penelitian, mayoritas keluarga pekerja migran memiliki latar belakang pendidikan lulus dari Sekolah Menengah Atas/sederajat. Hasil dari analysis of varian 
(anova) menyebutkan bahwa tidak terdapat perbedaan yang signifikan tingkat literasi finansial ditinjau dari latar belakang pendidikan keluarga pekerja migran. Hasil penelitian menyatakan bahwa terdapat perbedaan tingkat literasi finansial yang dikaji berdasarkan tingkat pendidikan, semakin tinggi jenjang pendidikan semakin tinggi pula tingkat literasi finansialnya (Keown, 2011). Hasil kajian memperlihatkan bahwa skor rata-rata masing-masing jenjang pendidikan tidak mempunyai perbedaan yang terlalu signifikan.

Hal tersebut sejalan dengan hasil deskriptif rata-rata tingkat literasi finansial keluarga pekerja migran. Meskipun tidak terdapat perbedaan secara signifikan, namun secara perhitungan tetap terdapat perbedaan antara masing-masing kelompok jenjang pendidikan. Hasil analisis rata-rata tingkat literasi finansial memaparkan bahwa keluarga pekerja migran yang lulus pada tingkat SD/sederajat memiliki tingkat literasi finansial yang tergolong sedang dengan rata-rata skor 29. Keluarga pekerja migran dengan lulusan SMP/sederajat memiliki tingkat literasi finansial pada kategori sedang dengan skor 28,12. Rata-rata tingkat literasi finansial keluarga pekerja migran yang memiliki latar belakang lulusan SMA/sederajat pada kategori sedang dengan skor 29,45. Untuk ratarata tingkat literasi keluarga pekerja migran dengan latar belakang lulusan perguruan tinggi masuk dalam kategori sedang dengan rata-rata skor 30,25.

Keluarga pekerja migran dengan latar belakang pendidikan sekolah dasar dan sekolah menengah pertama memiliki jumlah yang signifikan jika digabungkan. Keluarga pekerja migran dengan latar belakang pendidikan lulusan sekolah dasar dan sekolah menengah pertama cenderung masuk pada kategori berliterasi finansial rendah. Implikasi dari kecenderungan tersebut menyatakan bahwa keluarga pekerja migran memiliki kekurangan dalam memutuskan pengelolaan keuangan. Kekurangan pandangan dalam memutuskan pengelolaan keuangan beresiko pada keputusan keuangan yang kurang tepat. Mencegah kesalahan keluarga pekerja migran dalam mengambil keputusan pengelolaan keuangan, diperlukan program pemberdayaan dengan program pelatihan dan pendampingan. Program pemberdayaan ini secara khusus menyasar pada kelompok keluarga pekerja migran yang memiliki kecenderungan berliterasi rendah, sehingga keluarga pekerja migran mampu mengelola keuangan demi kesejahteraan masa depan keluarganya.

\section{Literasi Digital Ditinjau Dari Latar Belakang Pendidikan Keluarga Pekerja Migran}

Hasil penelitian ini menyatakan bahwa literasi digital ditinjau dari tingkat pendidikan keluarga pekerja migran terdapat berbedaan yang signifikan. Dalam penelitian ini masing-masing jenjang pendidikan menunjukkan nilai rata-rata yang semakin tinggi dari lulusan SD/sederajat sampai dengan lulusan perguruan tinggi. Meskipun memiliki rata-rata yang berbeda, tingkat literasi keluarga pekerja migran masih termasuk dalam kategori yang sama yakni kategori sedang.

Rata-rata tingkat literasi digital keluarga pekerja migran dari lulusan SD/sederajat masuk pada kategori sedang dengan skor 43,5. Keluarga pekerja migran yang merupakan Iulusan SMP/sederajat memiliki tingkat literasi sedang dengan skor 46,3. Tingkat literasi keluarga pekerja migran lulusan SMA/sederajat masuk dalam kategori sedang dengan skor 50,8. Sedangkan untuk keluarga pekerja migran yang lulus dari perguruan tinggi memiliki rata-rata nilai 53,8 yang juga masih dalam kategori sedang. Hasil uji analisis menunjukkan adanya perbedaan yang signifikan literasi digital berdasarkan tingkat pendidikan keluarga pekerja migran. Perbedaan tingkat literasi digital yang signifikan tersebut terdapat pada kelompok lulusan jenjang $\mathrm{SD} /$ sederajat dengan lulusan perguruan tinggi. 
Hal ini mengindikasikan bahwa keluarga pekerja migran yang merupakan lulusan perguruan tinggi lebih mampu dalam memahami indikator dalam literasi digital seperti pemanfaatan teknologi digital dalam mencari informasi baru, pengoperasioan alat maupun fitur-fitur teknologi digital, serta memanfaatkannya dalam komunikasi dan kolaborasi. Hasil penelitian juga menunjukkan bahwa terdapat perbedaan tingkat pendidikan dengan lama penggunaan perangkat digital. Seseorang dengan tingkat pendidikan tinggi memiliki lama waktu penggunaan perangkat digital yang lebih tinggi dibandingkan dengan tingkat pendidikan lain (Susanto \& Proboyekti, 2017). Hal tersebut diasumsikan bahwa seseorang dengan tingkat pendidikan tinggi lebih terbiasa dengan penggunaan perangkat digital. Penelitian lain yang menguatkan hasil kajian ini adalah sumber daya manusia yang rendah, ditandai dengan rata-rata tingkat pendidikan yang rendah memiliki pengaruh pada kemampuan mempelajari perangkat digital (Hadiyat, 2014). Implikasi jika keluarga pekerja migran dengan latar belakang pendidikan SD dan SMP cenderung memiliki literasi digital yang rendah sehingga mengalami kesulitan mengikuti perkembangan teknologi dengan baik.

Era revolusi industri 4.0 telah menggeser cara-cara yang kovensional dalam hubungan antar manusia. Keluarga pekerja migran memiliki kelemahan dalam komunikasi karena terpisah dengan jarak. Untuk mengatasinya keluarga pekerja migran harus mampu memanfaatkan dunia digital. Demikian pula terhadap akses keuangan digital seperti peer to peer lending, uang digital (e-money), paypall, bitcoin, dan produk keuangan digital lain yang memudahkan manusia saling bertransaksi serta menghilangkan batas-batas negara. Keluarga pekerja migran yang tidak paham terhadap teknologi akan berkutat pada cara-cara lama yang usang dan mulai ditinggalkan. Sejalan dengan pemanfaatan komunikasi di era digital, media juga mulai bergeser pada dunia digital. Kecepatan dan kemudahan mengakses website berita online dipandang memberikan solusi kepada masyarakat yang selalu berkeinginan untuk memperbarui informasi secara real time.

Kegagapan teknologi yang dihadapi keluarga pekerja migran dengan latar belakang pendidikan yang rendah akan memicu potensi keharmonisan keluarga, terutama pada komunikasi yang menjadi tidak intensif. Semakin mudahnya pengiriman uang melalui pemanfaatan perangkat digital yang tidak akan mungkin bisa dimaksimalkan penggunaannya jika keluarga pekerja migran gagap teknologi. Terganggunya komunikasi dan potensi tertundanya pengiriman uang (remitansi) karena masih memanfaatkan cara-cara lama berpotensi menggangu jalannya hubungan rumah tangga. Satu-satunya cara dalam meminimalisir potensi tersebut adalah keterbukaan cara berpikir keluarga pekerja migran terhadap teknologi digital. Keluarga pekerja migran harus memiliki cara pandang bahwa teknologi bersifat untuk memberikan kemudahan dan bukan sesuatu yang sulit dipelajari. Cara pandang tersebut akan lebih maksimal jika keluarga pekerja migran dibiasakan dengan akses dunia digital melalui pelatihanpelatihan pemanfaatan perangkat digital. Hal ini akan membantu proses kegiatan kehidupan mereka seperti komunikasi digital dan pemanfaatan e-banking dan produk keuangan digital lainnya.

\section{SIMPULAN DAN SARAN \\ Simpulan}

Keluarga pekerja migran yang cenderung memiliki tingkat literasi finansial maupun literasi digital yang rendah adalah keluarga pekerja migran dengan latar belakang lulusan SD dan SMP. Hal ini semakin menguatkan penelitian terdahulu yang menyatakan bahwa latar belakang pendidikan memberikan pengaruh terhadap tingkat kemampuan/literasi seseorang. Hasil tersebut dapat dimanfaatkan untuk menentukan 
intervensi bagi kelompok keluarga pekerja migran, yaitu intervensi peningkatan pengetahuan dan keterampilan berupa program pendidikan nonformal seperti pelatihan dan pemberdayaan bidang finansial maupun digital. Intervensi pendidikan tersebut berguna untuk mempersiapkan keluarga pekerja migran dalam era revolusi industri 4.0.

\section{Saran}

Keluarga pekerja migran dengan latar belakang pendidikan lulusan SD dan SMP untuk secara aktif dan mandiri mengeksplorasi programprogram pendidikan nonformal seperti pelatihan dan pemberdayaan. Lebih spesifik, keluarga pekerja migran dapat mengadakan kegiatan yang dapat meningkatkan literasi finansialnya seperti kegiatan arisan, membentuk koperasi, atau kelompok usaha bersama antarkeluarga pekerja migran yang pada akhirnya akan berdampak pada peningkatan kemampuan literasi.

Kementerian Tenaga Kerja dapat membuat kebijakan merekrut tenaga ahli berupa petugas lapangan yang memiliki keahlian di bidang pendidikan nonformal seperti pendampingan dan pemberdayaan masyarakat yang ditempatkan pada wilayah yang memiliki potensi pekerja migran yang tinggi. Fungsi dari petugas lapangan ini hendaknya dapat menerapkan program pendidikan nonformal seperti pendampingan, pemberdayaan, dan advokasi. Petugas ini juga bukan hanya terkait pemberangkatan dan penanganan masalah pekerja migran namun juga memberikan pendidikan, keterampilan, dan pendampingan kepada keluarga pekerja migran, terutama kepada keluarga pekerja migran yang cenderung memiliki tingkat literasi digital maupun finansial yang rendah.

\section{PUSTAKA ACUAN}

Alas, S. (2018). Analisis tingkat literasi masyarakat desa dalam pemanfaatan teknologi informasi \& komunikasi. Konferensi Nasional Sistem Informasi (KNSI) 2018.

Ansori, \& Samsudin, A. (2013). Transformasi pembelajaran di pendidkan non formal (Upaya mempersiapkan pendidik dan peserta didik dalam menghadapi tantangan global untuk menjadi manusia pembelajar). Jurnal EMPOWERMENT, 2(1), 1-15.

Beetham, H., McGill, L., \& Littlejohn, A. (2009). Thriving in the 21st century: Learning literacies for the digital age (LLiDA project): Executive Summary, Conclusions and recommendations. UK Joint Information Systems Committees (JISC).

Chen, H., \& Volpe, R.P. (1998). An analysis of personal financial literacy among college students. Financial Services Review, 7, 107-128. https://doi.org/10.1016/S1057-0810(99)80006-7.

Chinen, K. \& Endo, H. (2012). Effects of attitude and background on personal financial ability: A student survey in the United States. International Journal of Management, 29(1), 33-45.

Eisenberg, M.B. (2008). Information literacy: Essential skills for the information age. DESIDOC Journal of Library \& Information Technology, 28(2), 39-47.

Gilster, P. (1997). Digital literacy. New York: Wiley Computer Pub.

Hadiyat, Y.D. (2014). Kesenjangan digital di Indonesia (Studi Kasus di Kabupaten Wakatobi). Jurnal Pekommas, 17(2), 81-90. doi: 10.30818/jpkm.2014.1170203.

Huston, S.J. (2010). Measuring financial literacy. Journal of Consumer Affairs, 44(2), 296-316. doi: $10.1111 / \mathrm{j} .1745-6606.2010 .01170$.

Iskandar. (2008). Metodologi penelitian pendidikan dan sosial (Kuatitatif dan Kualitatif). Dalam $\mathrm{H}$. Martinis Yamin (Ed). Jakarta: GP Press. 
Keown, L.A. (2011). The financial knowledge of Canadians. Canadian Social Trends 91, 30-39.

King, H.A. (1978). A nomogram to assist in planning surveys of small $(n<2.000)$ populations. Journal Research Quarterly American Alliance for Health, Physical Education and Recreation, 49(4), 552-557. doi: 10.1080/10671315.1978.10615570.

Mason, C.L. \& Wilson, R. (2000). Conceptualising financial literacy. London: Loughborough University.

Otoritas Jasa Keuangan. (2017). Strategi nasional literasi keuangan Indonesia (Revisit 2017). URL https://www.ojk.go.id/id/berita-dan-kegiatan/publikasi/Documents/Pages/StrategiNasional-Literasi-Keuangan-Indonesia-(Revisit-2017)-/SNLKI\%20(Revisit\%202017).pdf.

Prasetyo, B. \& Trisyanti, U. (2018). Revolusi industri 4.0 dan tantangan perubahan sosial. Strategi Pembangunan Nasional Menghadapi Revolusi Industri 4.0. Dipresentasikan pada Prosiding SEMATEKSOS 3, Surabaya.

Remund, D.L. (2010). Financial literacy explicated: The case for a clearer definition in an increasingly complex economy. The Journal of consumer affairs 44(2), 276-295.

Samosir, F. (2014). Kemampuan literasi informasi mahasiswa pascasarjana (Studi deskriptif pascasarjana UGM dan UIN). Universitas Gadjah Mada, Yogyakarta.

Silvana, H. \& Darmawan, C. (2018). Pendidikan literasi digital di kalangan usia muda di kota bandung. PEDAGOGIA, 16(2), 146. doi: 10.17509/pdgia.v16i2.11327.

Sitorus, S.D.H. (2017). Pengaruh latar belakang pendidikan dan pengetahuan tentang akuntansi terhadap penggunaan sistem informasi akuntansi pada pedagang di wilayah kelurahan helvetia tengah medan. At-Tawassuth, $I I(2), 413-436$.

Susanto, B. \& Proboyekti, U. (2017). Identifikasi digital literacy untuk mengukur kesiapan jurnalisme warga. Prosiding: Annual Research Seminar (ARS). 2(1), 33-38. Universitas Sriwijaya. 